\title{
RACJONALNOŚĆ W UJĘCIU METAFORYCZNYM
}

\section{Wprowadzenie}

Problem racjonalności $\mathrm{w}$ ramach swojego wielostronnego i interdyscyplinarnego ujęcia - przeważają w nim na ogół perspektywy ontologiczna, epistemologiczna czy metodologiczna - bywa ujmowany również z językoznawczego punktu widzenia. Poza kwestiami poznawczego aspektu racjonalności - statusu i wartości poznania racjonalnego, w tym pytania, w jakim stopniu (i czy w ogóle) jest ono wyróżnionym rodzajem poznania - zwraca się również uwagę na językową formę, w jakiej pewne rodzaje działania i poznania człowieka są nazywane, definiowane, teoretyzowane jako racjonalne. Wprawdzie ujęcie problemu racjonalności od strony języka rodzi zazwyczaj obawy o relatywizm, który narusza czy wręcz podważa jego klasyczne ujęcie, można niemniej żywić przekonanie, oparte na wynikach analiz psychologicznych i językoznawczych, a także zwyczajów zwykłego wysławiania się na ten temat, że taka właśnie perspektywa badawcza wnosi wiele nowego do klasycznego problemu racjonalności. Relatywizm teoriopoznawczy nie jest zagrożeniem dla racjonalności, jeśli uwzględni się wielostronne zjawisko niezbywalnego i koniecznego zdeterminowania nie tylko mówienia i teoretyzowania w naukowym czy filozoficznym dyskursie na temat szeroko pojętej racjonalności praktyczno-poznawczej, ale także jej głębszego i wielostronnego doświadczania przez człowieka, w tym konceptualizowania działań i sposobów poznawania określanych jako „racjonalne”, a przebiegających według behawioralno-poznawczych schematów. W tekście niniejszym zaprezentowane jest takie właśnie ujęcie racjonalności, które uwzględnia szeroko rozumianą metaforyczność obecną zarówno w nazywaniu, jak i wyobrażaniu, a nawet działaniu, dzięki czemu problem racjonalności nabiera nowego wymiaru. 
Ryszard Kleszcz swoje epistemologiczno-metodologiczne badania nad racjonalnością sytuuje $\mathrm{w}$ ramach metafilozoficznego stanowiska, które w monografii $O$ racjonalności: Studium epistemologiczno-metodologiczne (1998) określa mianem „analitycznego, choć niescjentystycznego”. Jego specyfiką jest założenie, że filozofia jest aktywnością poznawcza, której głównym narzędziem jest dyskurs spełniający wymogi językowej ścisłości i precyzji wypowiedzi, logicznej niesprzeczności zdań, a także (co najważniejsze) wymogi argumentacyjne, takie jak przyjmowanie i głoszenie poglądów w wystarczający (tj. racjonalny) sposób uzasadnionych w proporcji do przyjmowanych założeń, w tym również intersubiektywnie sprawdzalnych oraz komunikowalnych. Pod tym względem filozoficzne analizy racjonalności różnią się, stwierdza Autor, od literackiego stylu, chociaż nie odbiegają zasadniczo od językowo-formalnego rygoru, jakim posługuje się nauka. Analizy racjonalności Kleszcz proponuje prowadzić jednak niezależnie od badań naukowych w takich dyscyplinach jak psychologia, socjologia, biologia czy psychologia ewolucyjna, które zajmują się niemniej przekonaniami i działaniami określanymi jako racjonalne. Według Autora problem determinującego wpływu środowiska przyrodniczego, społecznego czy politycznego na zachowania i przekonania człowieka nie jest ani tematem, ani metodą analiz epistemologiczno-metodologicznych racjonalności jako takiej. Czynniki determinujące racjonalne zachowania i przekonania człowieka „,wydają się wtórne czy wręcz nieistotne" dla filozofii - tak dla problemu, jak i metody badań tego, co racjonalne. Metodologia analiz filozoficznych (zasadniczo metafilozoficznych) i metodologia badań naukowych są różne, są sobie przeciwstawne. Autor kieruje się tylko pierwszą, drugą zaś wyklucza z obszaru analiz filozoficznych jako typ „niescjentystycznych analiz”. W filozofii liczą się, argumentuje, ogólne i uniwersalne metazasady racjonalności, którymi są: ścisłość językowa, przestrzeganie reguł logiki, krytycyzm oraz rozwiązywalność problemów. W nauce funkcjonują z kolei metody badań szczegółowych i zasady konkretne, zrelatywizowane przy tym do odpowiednich i wyróżnionych działań i przekonań racjonalnych człowieka, które dana dyscyplina naukowa bada; filozofia takiej relatywizacji stara się unikać.

Niemniej Kleszcz w znaczący sposób wyznaje: „Sądzę równocześnie, że twierdzenia nauki (nauk szczegółowych) nie są obojętne dla refleksji filozoficznej. [...] [w]ydobycie filozoficznych konsekwencji twierdzeń nauk wymaga zawsze odwołania się do zabiegów interpretacyjnych" (1998, s. 9). Nie można zatem obejść się w badaniu racjonalności, co warto na marginesie powyższej uwagi zauważyć, ani bez filozoficznej perspektywy, ani bez wyników naukowych badań - oba ujęcia racjonalności są potrzebne w poszukiwaniu jej różnych aspektów. 
Po analizie i odrzuceniu relatywizmu ogólnego w odniesieniu do prawdy i praw logiki oraz zanegowaniu relatywizacji stanowiska racjonalistycznego Autor przechodzi do ważnego pytania: jak uzasadnić wybór racjonalności? Jak uzasadnić nie racjonalność wprost, lecz uzasadnić wybór określonej koncepcji racjonalności. Inaczej mówiąc, jakie racje epistemiczne czy logiczne, ale również kulturowe (nie można ich nie uwzględniać), decydują o możliwości przyjęcia i uzasadnienia (tj. wyboru ze spektrum różnych jego alternatyw) racjonalności działań i przekonań człowieka, a w efekcie również akceptacji stanowiska racjonalizmu (również wyboru spośród licznych stanowisk)? Argumentacja na rzecz dwóch rzeczy: (1) racjonalizmu jako stanowiska oraz racjonalności jako cechy działań i przekonań jest zawsze wyborem spomiędzy wielu możliwych racji, czyli innych stanowisk, argumentacji na ich rzecz, w tym również, co nieuniknione, wyborem spomiędzy przesłanek na ich rzecz, którymi są zawsze określone twierdzenia naukowe. Obrona i uzasadnienie racjonalności to zawsze wybór argumentów, to odpowiedź na pytanie: dlaczego ta, a nie inna racjonalność? Jak zauważa Autor, zawsze „docieramy wcześniej czy później do pytania, dlaczego racjonalność?" (1998, s. 142). Podanie uzasadnienia racjonalności $\mathrm{w}$ dziedzinie filozofii, inaczej niż w naukach, w których stosuje się procedury uzasadniania, jest na ogół przytoczeniem jakichś argumentów. Idzie wskaże o podanie prawomocnych argumentów, stwierdza Kleszcz, wiarygodnie przemawiających na rzecz racjonalności, gdyż „brak argumentacji w kontekście dowolnych przekonań czyniłby je właśnie racjonalności pozbawionymi" (1998, s. 143). Bez przytoczenia prawomocnych argumentacji przekonanie, ale także i działanie nie może być racjonalne; nie jest racjonalne, gdyż nie ma wystarczającego powodu (tj. argumentu) jego uznania. Filozoficzna argumentacja na jego rzecz jest czymś innym niż, jak ma to miejsce w nauce, podanie samej przyczyny, np. biologicznej (ewolucyjnej) adaptacji, psychologicznej oczywistości czy reguły narzuconej przez społeczeństwo, które uzasadniałyby dane przekonanie za uznane racjonalnie. $\mathrm{W}$ istocie rzeczy, stwierdza Kleszcz, w niescjentystycznych analizach racjonalności (jak jego własna) stosuje się głównie argumentację filozoficzną, w której argumentacyjne uprawomocnianie łączy się z interpretacją, przez co argumentacja taka staje się hermeneutyka, czyli procedurą o charakterze retorycznym i perswazyjnym. „Argumentacja tego typu ma też charakter podmiotowy, co różni ją od uzasadniania" (Kleszcz 1998, s. 144), zauważa przy tym znacząco. Argumentacja subiektywna (podmiotowa) jest bowiem o wiele szersza i bardziej złożona niż naukowe uzasadnianie na podstawie obiektywnych kryteriów epistemiczno-logicznych. Oznacza to, że poza racjami epistemiczno-logicznymi ważną rolę odgrywają w filozoficznej argumentacji na rzecz racjonalności także czynniki subiektywne, 
podmiotowe, $\mathrm{w}$ tym społeczne i kulturowe. Takie poszerzenie zagadnienia uzasadniania racjonalności pociąga za sobą jednak pewne trudności, zauważa Autor. W jego dalszej argumentacji nie wydają się one jednak być zbyt dużym problemem interpretacyjnym. Kleszcz wylicza kilka z czynników (argumentów) podmiotowo-subiektywnych, do których zalicza: „wyższość technologiczną" czy „technologiczne sukcesy” wskazane przez C. Taylora, „uznawanie metod nauki za odpowiednie” w społecznościach akceptujących standardy racjonalności, które podaje A. Ayer, czy także, co jest najciekawszym argumentem, „zasadę praktycyzmu i postulatywizmu” oraz "postulaty jako wymagalniki praktyczne w postaci pożytecznej i nieodzownej fikcji" sformułowane przez N. Łubnickiego. Wszystkie one wskazuja, co warto zauważyć w tym miejscu, że filozoficzne analizy racjonalności mogą przywoływać i szeroko wykorzystywać argumentację wskazującą na czynniki społeczne i kulturowe, których działanie badania racjonalności muszą uwzględniać.

\section{Racjonalność widziana przez pryzmat języka}

Analizy racjonalności - zarówno stanowiska filozoficznego, jak i dystynktywnej cechy działań i przekonań człowieka - przeprowadzone przez Kleszcza wskazują na oczywisty fakt, że próby jej zdefiniowania, jak również podania kryteriów wyboru argumentacji (racji) na jej rzecz, w tym zwłaszcza uzasadniania tych racji, łączą się z własnościami języka i dyskursu, w ramach których są one podejmowane i przeprowadzane. Racjonalność rozpatrywana w wymiarze filozoficznym i epistemologiczno-metodologicznym jest w specyficzny sposób językocentryczna, co nie oznacza jednak, że do samych tylko analiz języka ma się ona sprowadzać.

Rola języka w problemie racjonalności to kwestia nie tylko środka (narzędzia lingwistycznego) opisu któregokolwiek ze szczegółowych zagadnień wchodzących w jego zakres, lecz szerzej - kwestia dyskursu i praktyk językowych, które zarówno opisują racjonalność, jak również, co najważniejsze, stwarzają ją oraz o niej decydują. O ile pierwszy aspekt racjonalności uwikłanej w kwestię języka Kleszcz uznaje i rozwija w ramach swoich analiz argumentacji filozoficznej, o tyle drugi nie jest u niego obecny. W niniejszym tekście przedstawiona zostaje możliwość ujęcia problemu racjonalności również $\mathrm{w}$ drugim aspekcie - determinującego wpływu na racjonalność działań i przekonań człowieka czynności językowego, w szczególności metaforycznego określania pewnych cech dystynktywnych racjonalności w powyższym znaczeniu. Metaforyczność wyrażeń czy związków frazeologicznych służących do opisu i klasyfikowania 
pewnych typów działań człowieka, w tym również grup ludzkich, uznać należy za ważny czynnik determinujący racjonalność zarówno jako stanowisko filozoficzne, jak i cechę działań oraz przekonań człowieka.

Na rolę kwestii językowych, głównie działań komunikacyjnych i aktów mowy, w badaniach nad racjonalnością wskazuje John Searle, rekonstruując i zarazem krytykując klasyczny model racjonalności. Wymienia w nim takie tradycyjnie uznawane warunki (tj. racje konieczne) racjonalności, jak: dominującą rolę rozumu (podporządkowującego sobie w poznaniu zmysły i uczucia), stosowanie się do reguł logiki, spójność przekonań (z wyjątkiem dla złego działania woli uchylającej rozumność działania) czy pragmatyczną kalkulację między środkami a celami działania racjonalnego. Krytykując ów model za narzucenie w filozofii, w nauce i potocznym doświadczeniu jego wyidealizowanej wartości, w monografii Rationality in Action Searle stwierdza:

Ograniczenia racjonalności są uniwersalne i wbudowane w strukturę umysłu i języka, w szczególności w struktury intencjonalności i aktów mowy. Można opisać działanie tych ograniczeń, tak jak próbuję to zrobić, można też krytykować ten opis, czego również próbuję dokonać, lecz racjonalność jako taka ani nie wymaga, ani nie dopuszcza uzasadniania, ponieważ wszelkie myślenie i język, tym samym wszelka argumentacja, zakładają racjonalność. Można w racjonalny sposób dyskutować z teoriami racjonalności, lecz nie z racjonalnością (2001, s. xiv).

Autor zauważa w modelu wiele trafnych elementów - współgranie motywów i celów ze środkami w koncepcji tzw. racjonalności instrumentalnej - i uważa jednocześnie, że racjonalność działań poznawczych i praktycznych nie znajduje uzasadnienia w postaci wyłącznie racji logicznych; powodami uznawania działań i poznania za racjonalne są motywy psychologiczne działających ludzi. Przyczyny racjonalnego działania znajdują się w nim samym, a nie w zewnętrznych, wyidealizowanych racjach. Racjonalność jest kształtowana w ramach językowych operacji i strategii mówienia oraz komunikowania się, które występują w określonym dyskursie. W sposobach mówienia i komunikowania przekonań w obrębie danej wspólnoty językowej powstają i utrwalają się argumenty na rzecz przyjęcia wystarczająco uzasadnionych przekonań, zdobywających potwierdzenie, akceptację oraz uznanie. „Racjonalne” znaczy tyle co komunikowalne i akceptowalne we wspólnocie posługującej się wspólnym językiem i jego własnymi, wewnętrznymi warunkami poprawności i komunikowalności.

W swoich badaniach Searle stawia pytanie o naturę racjonalnych argumentacji, Stwierdza, że powstają one w aktach mowy, w ramach dyskursu, kiedy mówiący odnosi się do siebie samego, a także nawiązuje 
specjalną relację z innymi członkami wspólnoty. Relacje te mają charakter epistemiczno-lingwistycznego obustronnego powiązania stron dyskursu, są racjonalne ze względu na tę właśnie obustronność. Racjonalne racje są zobowiązaniami o charakterze angażująco-obligujących działań (commitments), które podmiot przyjmuje wobec siebie samego w trakcie formułowania swoich sądów i przekonań oraz wypowiadania wobec innych osób zdań twierdzących coś na ich temat. Sądy z asercją stwierdza Searle, przyjmujące formę wypowiedzi orzekających nie tylko o danym stanie rzeczy, ale również deklarujących wiarę mówiącego w ich prawdziwość (tj. adekwatność sądu oraz prawdziwość zdania), są podstawą zobowiązania, jakie podmiot przyjmuje wobec siebie ze względu na warunki prawdziwości i wiarygodności sądu, przekonania oraz aktu mowy. „Wypowiedzenie prawdziwościowych warunków jest zobowiązaniem do działania", stwierdza wyraźnie Searle (2001, s. 170). W szczególności gdy akt mowy z asercją prawdziwościową jest formułowany w sferze publicznej, wobec szerokiej publiczności, to działanie podmiotu nabiera charakteru świadomego zobowiązania. Ma wówczas podwójny charakter i podwójną moc - po pierwsze, jest nabyciem przez podmiot (meta)przekonania o słuszności własnego przekonania; po drugie, i co jest ważniejsze, staje się zobowiązaniem wobec innych osób. W każdym z tych przypadków racjonalność przekonań i działań wynika z subiektywno-obiektywnych zobowiązań podmiotu, które nadają ich racjonalności nie tylko epistemologiczny czy logiczny, ale również moralny charakter. Aby być w pełni racjonalnym w działaniu i twierdzeniu czegokolwiek o świecie, trzeba uświadomić sobie, stwierdza Searle, własne intencje i zobowiązania prawdziwościowego orzekania i mówienia oraz rozpoznać, a także stosować, epistemiczne i logiczne racje dla takiego działania. „Wystarczy rozpoznać racjonalność, jej uznanie jest wówczas wystarczające. Musimy po prostu rozpoznać nasze własne samo wytwarzające się zobowiązania i ich logiczne konsekwencje" (Searle 2001, s. 181). I jedno (tj. samoświadomość zobligowanego podmiotu), i drugie (tj. zinterioryzowana treść zobowiązania) gwarantuje posługiwanie się racjonalnymi powodami działania. Racjonalność tak zinterpretowana uwolniona jest od subiektywistycznej (wyłącznie podmiotowej) interpretacji, gdyż jej główny warunek (racja dostateczna i konieczna zarazem) nie leży w pragnieniu podmiotu, aby być racjonalnym, lecz $\mathrm{w}$ zobiektywizowanej i zinterioryzowanej intencji (tj. celu, zamiarze) obligującej go do racjonalnego działania w ramach wspólnoty konwersacyjno-dyskursywnej.

Searle stawia w swoich rozważaniach pytanie: czy łatwo jest osiągnąć rodzaj racjonalności, który nie odwołuje się do transcendentnych racji, 
lecz opiera się na wewnętrznych motywach (nie pragnieniach a tylko intencjach, sama wola bowiem nie wystarcza), uzależniając go jednocześnie od społecznych warunków? Jego odpowiedź jest w duchu anty-Kantowskim (odrzuca transcendalistyczne kryteria racjonalności), z mocnym akcentem na lingwistyczny wymiar problemu; powyższy dylemat rozwiązać można tylko w ramach analiz funkcjonowania języka, zwłaszcza badania terminologii odnoszącej się (definiującej, porównującej itp.) do rozumności. Autor zauważa w tej sprawie następującą rzecz:

Gdyby jedynym sposobem, w którym mielibyśmy współpracować z innymi ludźmi, miałoby być stawianie ich w pozycji, w której, niezależnie od nas, mieliby pragnąc tego, czego my pragniemy od nich, większość form życia społecznego nie byłaby możliwa.

Jedynym sposobem zorganizowania czasowego wymiaru życia społecznego jest wytworzenie mechanizmów uzasadniania racjonalnych oczekiwań na temat przyszłego zachowania się członków wspólnoty, łącznie z nami samymi (Searle 2001, s. 206).

Z uwag Searle'a można wyprowadzić ważną konsekwencję wynikającą z przyjęcia językocentrycznego nastawienia $\mathrm{w}$ badaniach racjonalności; nastawienie to owocuje znaczącą (w znaczeniu zaproponowanym przez Kleszcza) argumentacją tak filozoficzną, jak i naukową (lingwistyczną i psycholingwistyczną). Aby działać w zbiorowości w pełni racjonalnie - według ideału racjonalności instrumentalnej (dostosowującej cele do środków), a nie absolutystycznej (przedkładającej cele nad środkami) - konieczne jest, jak wynika z argumentacji Searle'a, jedno jeszcze ważne nastawienie intencjonalne podmiotu praktyczno-poznawczych czynów - przypisywanie racjonalności innym uczestnikom wspólnotowego działania. Racjonalność to nie tylko zewnętrzny ideał czy zbiór cech skutecznego działania, lecz również intencyjne nastawienie pragmatyczne podmiotu wyrażające się w przypisaniu (atrybucji) tego, co „racjonalne”, innym ludziom. Racjonalność jest praktyczną regułą współdziałania w grupie, którą jej członkowie przypisują sobie nawzajem jako cechę dystynktywną; brak takiego nastawienia uniemożliwiałby współdziałanie. Bez atrybutywistycznej (dyrektywalnej w sensie obowiązującej i zobowiązującej reguły) własności racjonalność byłaby pustym ideałem; ten właśnie aspekt racjonalności jest uwypuklony przez jej analizy językowe. 


\section{Metaforyczne ujęcie problemu racjonalności jednostek i grup}

Językowe ujęcie problemu racjonalności wyraża się w szczególny sposób w metaforycznych zwrotach opisujących działania jednostek i grup społecznych, co następuje poprzez ich zestawienia i porównania. Metafory używane do opisu racjonalnych zachowań i poznawczych czynności jednostki przenoszą własności zachowań poszczególnego człowieka na działania grup i zbiorowości, a także instytucji. Dzięki przenośniom i parabolom opisuje się to co, nowe i nieznane ( $\mathrm{zw}$. domenę docelową - szczególne, złożone zachowanie grupy), za pomocą tego, co proste i już znane (tzw. domenę źródłową - typowe zachowanie się jednostki); racjonalność jednostki jest tym samym metaforycznie przypisywana zbiorowością określanym przez to również jako racjonalne. Takie ujęcie problemu racjonalności ma dwa aspekty szczegółowe, które sprowadzają się do dwóch mechanizmów językowo-poznawczych, w których działanie jednostek i grup wyobrażane i nazywane jest jako „racjonalne”. Pierwszy, prosty i łatwy do rozpoznania, polega na dokonującej się za sprawą metaforycznych zwrotów (w ich opisowej oraz komunikacyjnej funkcji) ekstrapolacji jednostkowej racjonalności na działania grup, którym tym sposobem przypisuje się racjonalność grupową; własności takiej nie rozpoznałoby się ani nie uznało za cechę dystynktywną bez tego właśnie parabolicznego porównania i nazwania. Drugi mechanizm, odkrywany i badany przez kognitywistycznie nastawionych językoznawców, polega na tym, że o działaniu człowieka (tak jednostkowym, jak i zbiorowym) myśli się $w$ ramach pewnych umysłowo-behawioralnych schematów pojęciowych (leżących u podstaw metaforycznych zwrotów i wyrażeń), w których dominują konotacje przestrzenne, porządkujące, ukierunkowujące itp.; na skutek tego właśnie mechanizmu za racjonalne uznawane są te działania, które wykazują się sekwencyjnością uporządkowaniem i przyczynowo-skutkową strukturą. Oba mechanizmy opierają się na zdolności człowieka do rozpoznawania analogii i podobieństw wśród różnorodnych rzeczy, zdarzeń i procesów oraz na ich parabolicznym, figuratywnym, czyli metaforycznym nazywaniu.

Uzusem językowym zarówno potocznego wysławiania się, jak i specjalistycznych (np. prawniczych, ekonomicznych czy politycznych) dyskursów odnoszących się do pewnych zachowań człowieka i określonych grup społecznych są zwroty w rodzaju: „ONZ podjęło kolejna, po wcześniejszych nieudanych, próbę pokojowych negocjacji”, "Zarząd firmy krok po kroku skalkulował koszty i zyski”, ,Rząd prawicowy nieustannie opiekuje się uboższymi obywatelami tak jak ojciec rodziny swoimi 
dziećmi”, „Ława przysięgłych sformułowała po długiej deliberacji swój werdykt", "Sąd wydał, uzasadnił i ogłosił do publicznej wiadomości surowy i sprawiedliwy wyrok" itp. Spotkać je można w wypowiedziach naukowych, komentarzach fachowców i ekspertów, w medialnych doniesieniach, w codziennym wysławianiu się. Formułowane są w odniesieniu do zachowań zbiorowych podmiotów - grup konkretnych ludzi i bardziej abstrakcyjnych (anonimowych) organizacji - których działanie jest intencjonalnie nastawione na osiągnięcie pewnego celu (np. zażegnania konfliktu, opieki, ukarania, itp.) z użyciem określonych środków i sposobów działania (np. negocjacji, kalkulacji, opiekowania się, osądzania i ogłoszenia sentencji wyroku), a także nastawione na wartości (pokoju, dobrobytu, sprawiedliwości); wszystkie one mają w swoich treściach wyraźne odniesienie do idei racjonalności instrumentalnej. Zwroty te, rozpatrywane od strony zarówno lingwistycznej, jak i psychologicznej (psycho-lingwistycznej), mają dwie znaczące własności (funkcje).

Po pierwsze, założona jest w nich sugestia, że grupa czy organizacja (tj. zbiór jednostek w sensie bardziej dystrybutywnym niż kolektywnym) działa tak samo jak jednostka - podejmuje racjonalne działania i decyzje, opierając się na takich czynnościach poznawczych jak rozważanie argumentów, planowanie, obliczanie skutków, przyjmowanie odpowiedzialności za działanie. Rząd bywa przyrównywany do surowego, lecz opiekuńczego ojca rodziny, zarząd firmy do skrupulatnego księgowego, sąd do surowego i sprawiedliwego człowieka. Słowem, podmiot zbiorowy jest równy w swoich intencjach, predyspozycjach poznawczych oraz dyspozycjach do działania podmiotowi jednostkowemu; zbiorowość może być tak samo racjonalna, jak jest nią jednostka; obu typów racjonalności nic nie różni, są tego samego rodzaju, mają podobną strukturę. Zrównanie ich jest następstwem metaforycznego mówienia, które w powyższych przykładach przyjmuje postać schematu: „Grupa działa (racjonalnie) tak jak pojedynczy człowiek”, ",Zbiorowy podmiot jest racjonalny, jak gdyby był jednostką". Sformułowania w rodzaju: "tak jak" lub ,jak gdyby", typowe dla parabolicznych, figuratywnych określeń występujących w metaforach języka mówionego, a także tekstu, decydują o kategorialnym zrównaniu racjonalności jednostek i domniemanej racjonalności zbiorowego podmiotu. W ramach dyskusji nad klasyczną racjonalnością zależność taką rozpoznał już Anthony Quinton, pisząc:

W swobodny sposób mówimy o umysłowych własnościach i faktach odnoszących się do grupy w sposób, w jaki czynimy w odniesieniu do pojedynczych ludzi. Mówi się o grupach, że posiadają przekonania, emocje i postawy, jak również podejmują decyzje czy czynią obietnice. Lecz sposoby takiego mówienia są czysto metaforyczne (1975, s. 17). 
Zależność ta ma jednak, na co warto zwrócić uwagę, o wiele bardziej złożoną naturę. Zwroty języka wprawdzie narzucają i utrwalają zrównywanie obu racjonalności, lecz tym, co zasadniczo je ugruntowuje, jest sposób myślenia i wyobrażania (konceptualizowania) sobie tego, czym racjonalność jednostkowa lub zbiorowa w ogóle jest.

Po drugie, powyższe zwroty wyrażają nie tylko przekonanie, że racjonalność jest cechą dającą się tak samo przypisać jednostkom, jak i zbiorowości, ale także, co najważniejsze, że ich struktura metaforyczno-pojęciowa - tj. korelacja mówienia metaforycznego z myśleniem metaforycznym, ich wzajemne przenikanie się i uwikłania - tę pierwszą własność zasadniczo i pierwotnie determinuje. Mówienie o grupie jak o jednostce, o ich podobnej i wspólnej racjonalności, wyrasta ze specyficznego myślenia o działaniu jako racjonalności wcielonej w konkretne zachowania niezależnie od tego, kto je wykonuje - jednostka czy grupa, a nawet instytucja czy organizacja. Metaforyczne wypowiadanie się o indywidualnych i zbiorowych podmiotach wyrasta ze specyficznie metaforycznego doświadczania ludzkiego zachowania się, u podstaw którego leżą konkretne schematy działania człowieka wobec środowiska.

\section{4. Racjonalność jednostek i grup - mechanizmy porównania i przeniesienia}

Na uwarunkowanie metaforycznego mówienia o racjonalności cielesnym doświadczaniem przez człowieka jego otoczenia zwracają uwagę George Lakoff i Mark Johnson (2010; 1999) w badaniach metaforyczności; wymowny tytułowy zwrot o „metaforach w naszym życiu” wskazuje na ich powszechną obecność w każdej formie doświadczania przez człowieka rzeczywistości. Autorzy mówią o schematach pojęciowych, które stanowią wyposażenie umysłu człowieka w doświadczaniu tak prostych rzeczy, procesów czy zdarzeń, jak i tych najbardziej złożonych i niejawnych. Decydują one o metaforycznych wyrażeniach i związkach frazeologicznych, które wynikają z nich wtórnie, są w stosunku do nich pochodne; wpierw bowiem człowiek rozpoznaje i doświadcza podobieństw oraz analogii pomiędzy różnymi rzeczami i zdarzeniami, a dopiero potem formułuje je językowo. Typowymi schematami pojęciowymi są: zestawianie rzeczy za pomocą związku przyczynowo-skutkowego, ujmowanie ich położenia w schematach: góra-dół, przód-tył, sytuowanie $\mathrm{w}$ układzie horyzontalnym lub wertykalnym, doświadczanie powiązań czasowych między rzeczami jako prostego następstwa, równoległości, synchronicznego-diachronicznego powiązania, a także ujmowanie ich w kategoriach przestrzeni, pojemnika czy też manipulowania rzeczami. 
Stanowią one strukturę umysłu i decydują o działaniu człowieka. Wyrażają się w proprioceptywnym, kinestetycznym, cielesnym doświadczeniu $\mathrm{w}$ jego otoczeniu. Ze względu na schematy pojęciowe nazywa rzeczy i zdarzenia, wypowiada się o doznawanych sytuacjach, a formułowane wyrażenia mają właśnie postać metafor, gdyż w schematach tych ujmuje przede wszystkim kluczowe dla metaforyczności podobieństwa między rzeczami i zdarzeniami. Człowiek mówi metaforycznie, ponieważ działa metaforycznie, stwierdzają Lakoff i Johnson.

Metaforyczność na poziomie języka jest na różne sposoby (dosłownie i w przenośni) ucieleśniona w ludzkim organizmie i jego zachowaniach - od gestów i mimiki twarzy przez mówienie (mowę ciała) po sposoby używania artefaktów (tekstów, dzieł sztuki, wizualnych przedstawień itp.) w celu reprezentowania przez nie odpowiednich stanów umysłowych. Ciało człowieka i jego zachowanie się, nie mniej niż sama mowa, są metaforyczne w swoim funkcjonowaniu. Tak rozumiane ucieleśnienie ma skutki również w sposobie teoretycznego ujmowania zachowania ludzkiego. Koncepcje i teorie racjonalności są także, na co zwracają uwagę Lakoff i Johnson, „ucieleśnione” w sposób, który polega na tym, że w terminologii opisującej zwłaszcza grupowe działania pojawiają się zwroty odnoszące się do tych zachowań ludzkiego organizmu, które mówią o prostych doświadczeniach praktyczno-poznawczych o czasowo-przestrzennych konotacjach. Na przykładzie podanych powyżej (w rozdziale 3) zwrotów mówiących o podmiotach zbiorowych (tj. organizacji politycznej, zarządzie firmy, rządzie czy sądzie lub ławie przysięgłych), porównywanych co do cech ich działania z działaniem jednostek, metaforyczne przypisanie im racjonalności zbiorowej następuje na podstawie schematów pojęciowych zdefiniowanych przez Lakoffa i Johnsona. W schematach pojęciowych tego rodzaju czynności poznawcze grupy ujmuje się $\mathrm{w}$ schematach przestrzenno-czasowych typu: przód-tył, góra-dół czy przed-po, ciągle-z przerwami, wewnątrz-na zewnątrz, ku czemuś, coś w czymś itp. Lakoff i Johnson określają je mianem „metafor orientacyjnych”, które organizują zarówno myślenie, jak i działanie człowieka i grup. „Metafory orientacyjne mają jako swoje źródło doświadczenie fizyczne i kulturowe; nie powstają więc przypadkowo. Dlatego metafora może służyć jako nośnik rozumienia jakiegoś pojęcia jedynie ze względu na jej podstawę doświadczeniową" (Lakoff, Johnson 2010, s. 46). Za takie właśnie metafory orientacyjne można uznać doświadczenia dające się przypisać wspomnianym powyżej grupom i organizacjom: (1) ONZ-owi, zarządowi firmy, rządowi państwa, (4) ławie przysięgłych, (5) sądowi. Są to odpowiednie reakcje, zachowania i działania: (1') podjęcie kolejnej (tj. następującej po sobie, jedna za drugą) próby negocjacji, ( $\left.2^{\prime}\right)$ sekwencyjne (tj. krok po kroku, algorytmiczne) kalkulowanie kosztów, ( $\left.3^{\prime}\right)$ nieustanne (tj. bez ograniczeń 
w czasie) opiekowanie się obywatelami, (4') długa (rozciągnięta w czasie) deliberacja zakończona (wyróżniony moment czasu) werdyktem (opinia włożona w słowa-pojemnik), czy też (5') przekazanie (jednorazowe działanie podjęte w jednym miejscu) sentencji wyroku (zachodzi tu wyobrażenie słów jako pojemnika dla treści myśli) do szerokiej publicznej przestrzeni/wiadomości (przeniesienie/rozesłanie w nieograniczoną przestrzeń). W każdym z tych przypadków grupowy podmiot działa w określonym czasie (kolejno, sekwencyjnie albo jednorazowo), robi coś wobec rzeczy czy zdarzeń oraz używa instrumentów i środków działania (oblicza, manipuluje, zarządza), słowem: stosuje się do metafor orientacyjnych. W szczególności, jak ma to miejsce podczas ogłaszania decyzji ławy przysięgłych czy werdyktu sądowego, grupowy podmiot postępuje według dwóch elementarnych schematów pojęciowych: pojemnika (myśli i decyzje zostają włożone w słowa oświadczenia lub tekst uzasadnienia wyroku) oraz przestrzeni (decyzje i werdykty upowszechniane są poza obręb grupy, ku czemuś, dla kogoś, na zewnątrz).

Lakoff i Johnson stwierdzają że racjonalne działanie tak jednostki, jak i grupy jest wyrazem podobnego (analogicznego w strukturze) doświadczenia; grupowe doświadczenia w zakresie podejmowania decyzji czy rozwiązywania problemów są podobne do indywidualnych doświadczeń,

216 rządzą się bowiem podobnymi metaforami orientacyjnymi. Ich schematy pojęciowe - zakorzenione $\mathrm{w}$ działaniach zachodzących $\mathrm{w}$ podobnych warunkach czasu i przestrzeni - decydują również o tym, że oba podmioty w jednakowy sposób uznają i nazywają swoje działania jako racjonalne. Racjonalne działanie znaczy w tym przypadku tyle co przebiegające sekwencyjnie, w uporządkowany, kontrolowany i korygowany sposób. Jest ono skierowane na zewnątrz, ku czemuś/komuś, przebiega jawnie, w intersubiektywnie zrozumiały sposób, akceptowalny przez wszystkich. Racjonalność jednostkowa i grupowa wyrasta z głębszych sposobów doświadczenia świata przez oba typy podmiotów. Nazywanie takiego doświadczania literalnie (tj. zgodnie z konwencją językową zachodniej filozofii) „racjonalnym" jest wszelako wtórne w stosunku do jego pierwotnie metaforycznej - w sensie ucieleśnionej w zachowaniu i w języku - natury.

\section{Opisywanie versus przypisywanie racjonalności}

Podsumowując powyższe rozważania, warto zwrócić uwagę na fakt ogólniejszej natury - metafilozoficznej w znaczeniu, jakie nadaje mu Kleszcz w swoich „niescjentystycznych analizach”. Racjonalność jako cecha dystynktywna działania i poznawania jest na ogół powiązana z jednostkami i grupami na dwa sposoby; są one odmienne i zarazem 
dopełniające się. Jest mianowicie racjonalność: (1) rozpoznawana w obrębie tego działania, na wybranych przykładach, oraz opisywana za pomocą terminologii właściwej dla języka potocznego, naukowego lub filozoficznego jako cecha dystynktywna określonego działania i doświadczania jednostki lub grupy. Jest ponadto: przypisywana temu działaniu według określonej konwencji (paradygmatów) oraz wartościowana w ramach jakiejś filozoficznej, naukowej lub potocznej teorii takiego działania. W pierwszym przypadku racjonalność jest cechą i własnością samego działania, w drugim jest wartością oraz oceną tego działania. Sposoby określania racjonalności: z jednej strony opisowy i deskryptywny, z drugiej wartościujący i preskryptywny (dyrektywalny), są spotykane powszechnie zarówno w dziejach europejskiej filozofii, jak i w dyskusjach $\mathrm{w}$ obrębie nauki czy w potocznym dyskursie. Oba aspekty racjonalności funkcjonują zazwyczaj synchronicznie, a nie diachronicznie, chociaż ich zależność chronologiczna może przybierać różne postaci, wyrażając się na ogół w formie związku funkcjonalnego; niepodobna dokonać w badaniach racjonalności jej opisu bez elementów wartościowania ani jej wartościowania bez samego opisu. Racjonalność zarówno działania, jak i teorii tego działania jest ponadto, na co wskazują badania Lakoffa i Johnsona, metaforycznie ustanawiana poprzez czynności jej doświadczenia bezpośredniego, które jest rozpoznaniem stanu rzeczy jako racjonalnego właśnie, a także doświadczenia pośredniego, które z kolei polega na przypisywaniu (atrybucji) tej cechy do określonego działania według schematów doświadczenia (np. metafor orientacyjnych).

Oba typy, by tak rzec, „racjonalizacji” działania i jego teorii, dokonujące się poprzez rozpoznanie lub/oraz przypisanie obu kategoriom kluczowej cechy, były w historii problemu racjonalności niejednokrotnie ujawniane i zapewne będą w jego badaniach wciąż obecne. Spotyka się je w klasycznych i tradycyjnych stanowiskach (podsumowanych przez Searle'a w rozdziale 2), a także w próbach wykroczenia poza ten paradygmat, czego przykładem jest stanowisko H. Simona (1983) określane jako „racjonalność ograniczona" (bounded rationality). W polemice $\mathrm{z}$ „olimpijską teorią racjonalności pełnej”, z „modelem umysłu boskiego” (tj. racjonalnością absolutną w znaczeniu Kartezjusza czy I. Kanta, a także E. Husserla), Simon wskazuje na rzeczywiste korzenie tego ideału. Zauważa mianowicie, że na jego powstanie oraz utrwalenie się wpływ miał matematyczny model racjonalności, który, stworzony w teorii gier, miał i wciąż ma zastosowanie $\mathrm{w}$ dziedzinie ekonomii. Zakłada się w nim, że optymalne (w tym sensie racjonalne) działanie podmiotu - jest nim „wyidealizowany decydent" (idealized decision-maker) - przebiega według następującego schematu: 
(1) decydent dysponuje „dobrze zdefiniowaną funkcją użyteczności";

(2) ma do czynienia z równie „dobrze zdefiniowanym zestawem alternatyw, spośród których dokonuje wyboru";

(3) może określić „spójny rozkład prawdopodobieństwa dla wszystkich przyszłych zdarzeń", aby w końcu

(4) nabrać „,woli (lub powinności) wybierania alternatyw, lub też wytworzyć strategię, która będzie maksymalizowała wartość (w granicach jego funkcji użyteczności) w stosunku do zestawu zdarzeń właściwych dla tej strategii" (Simon 1983, s. 34-35).

Krótko mówiąc, decydent taki działa jak Rozum opisany już w klasycznym racjonalizmie nowożytnej filozofii. Racjonalność w ramach zmatematyzowanego i formalnego modelu jest jednak, argumentuje Simon, jedynie modelem i nie ma uniwersalnego zastosowania; stosuje się zaledwie $\mathrm{w}$ nielicznych i wąskich obszarach zautomatyzowanego i przewidywalnego działania. W strukturze ludzkiego działania nie ma stałych i niezmiennych elementów w rodzaju "funkcji optymalnej i maksymalnej użyteczności", która miałaby być obliczana w ramach niezawodnego modelu matematycznego. Człowiek kieruje się wprawdzie użytecznością w swoich działaniach, ale nie ma niezawodnej reguły ustanawiania jej wartości najwyższej i niezmiennej; pozostaje tylko dobieranie środków do celów w ramach racjonalności instrumentalnej.

Simon koncepcję racjonalności instrumentalnej opisuje, co jest znamienne, wyrażeniami wysoce metaforycznymi i personifikującymi: „Rozum jest w pełni instrumentalny. Nie może nam powiedzieć, dokąd iść. Jest jak wynajęty rewolwerowiec, którego zatrudniamy do zrealizowania dowolnych celów, które sobie wyznaczamy, dobrych lub złych" (Simon 1983, s. 7-8). Działanie rozumu podlega personifikacji (rozum tradycyjny nic nie mówi, zaś rozum instrumentalny działa jak wynajęty rewolwerowiec, jest złoczyńcą). Zostaje ono nazwane „instrumentalnym” przez odwołanie się (w dystynktywnej funkcji tego metaforycznego określenia - użycie instrumentu jest najważniejszą cechą każdego ludzkiego działania) do środków i narzędzi, którymi człowiek dysponuje, ale także (co najważniejsze dla sensu argumentacji przedstawianej w niniejszym tekście) zostaje przyrównane i sprowadzone do beznamiętnej manipulacji dowolnymi środkami wykorzystywanymi w realizacji konkretnego (też dowolnego) celu. Działanie rozumu/rewolwerowca jest, według schematu metaforyczności ucieleśnionej, opisane jako wielokierunkowe, służące "do zrealizowania dowolnych celów", co oznacza zmierzanie w wielu kierunkach, a nie w jednym wyróżnionym, co konotuje z kolei ideał „rozumu olimpijskiego", wskazującego na jeden kierunek działania. Jest ono także neutralnie wartościowane, co wyraża się na dwa sposoby: 
(1) Immoralny rozum/rewolwerowiec „nie może nam powiedzieć, dokąd iść", co znaczy, że człowiek, działając racjonalnie (tj. instrumentalnie), nie podlega $z$ tego tytułu ocenie co do wybranego celu, lecz jedynie co do zastosowanych środków. To z kolei implikuje, że

(2) teoria rozumu instrumentalnego jest również neutralna aksjologicznie; nie przyjmuje żadnego z typów wartościowania charakterystycznego dla sporów między klasycznym (filozoficzno-etycznym) racjonalizmem a empiryzmem czy też między racjonalizmem a irracjonalizmem. Jest $\mathrm{w}$ tym zakresie neutralna, gdyż $\mathrm{w}$ teoretycznym opisie czynności instrumentalnego działania wskazuje na jego zewnętrzne, a nie immanentne warunki. Innymi słowami, teoria racjonalności ani nie nakłada na siebie nadmiernych zobowiązań - nie krytykuje i nie poucza bowiem innych teorii - ani nie ponosi odpowiedzialności za treść swojej koncepcji rozumności; ona tylko tę rozumność opisuje. Teoria racjonalności instrumentalnej postępuje zgodnie ze strukturą metaforycznego doświadczenia - funkcjonuje tak jak ów wynajęty rewolwerowiec, który nie ponosi $\mathrm{w}$ pełni odpowiedzialności za swoje postępowanie. Teoria ta odwołuje się pierwotnie i ostatecznie do doświadczenia życiowego człowieka, wyrasta z niego, a nie z innych (samych tylko) teorii; ten właśnie metateoretyczny (metafilozoficzny) fakt decyduje o jej specyficznym metodologiczno-aksjologicznym charakterze.

Podobnie sposób teoretyzowania racjonalności ujmują Lakoff i Johnson, kiedy piszą o ekonomicznym modelu działania podmiotów na rynku, a zwłaszcza o sposobie jego odnoszenia się do takiego działania. Na rynku działają złożone i na ogół przypadkowe oraz probabilistycznie opisywane i konwencjonalnie definiowane zjawiska i siły, które nie dają się opisać za pomocą modelu klasycznie pojmowanej racjonalności. Działanie jednostek lub grup na rynku nie jest ani racjonalne, ani nieracjonalne; układa się w sekwencję zdarzeń, których tendencje i znaczenie dają się określić jedynie za pomocą klasyfikującego i oceniającego modelu. Model wszakże nie opisuje racjonalności obiektywnie, a tylko konwencjonalnie, przypisując ją pewnym tylko działaniom, nazywając je „racjonalnymi”, inne zaś „nieracjonalnymi". Pełny i obiektywny opis zakładałby istnienie kontrowersyjnej „olimpijskiej racjonalności”. Poza częściowo adekwatnym opisem, który jest konieczny tak w nauce, jak i w praktyce ekonomicznego działania, pozostaje na ogół, stwierdzają Lakoff i Johnson, przypisanie i atrybucja kluczowej cechy racjonalności do wyróżnionych typów działania. Nie jest to nazbyt kłopotliwa od strony metodologicznej procedura, argumentują autorzy, gdyż jej przyjęcie uzasadnia praktyka naukowa ekonomii, w której wymodelowane zjawiska gospodarcze i rynkowe stają się 
tematem bardziej jeszcze szczegółowych badań. „Model racjonalnego wyboru nie jest po prostu o-pisany w stosunku do zwykłego działania, jest on raczej mu przy-pisany; w jego ramach rynki są tak skrojone, aby mógł być on skutecznie używany" (Lakoff, Johnson 1999, s. 531). Racjonalne działanie podmiotów na rynku - szczególny przykład racjonalności homo oeconomicus - jest derywatem teorii i modelu, bez których ich opis nie byłby w ogóle możliwy. Niemożliwe byłoby ich badanie także bez metaforycznego - ucieleśnionego w typie codziennego i naukowego doświadczenia - ujęcia ich istoty; rynek ma być dobrze ujęty przez model do dalszego badania, tak jak skutecznie skrojone ubranie powinno zapewnić dobre jego noszenie. O genezie i wartości każdej z teorii racjonalności, tak samo jak o działaniu praktyczno-poznawczym parabolicznie i figuratywnie określanym mianem "racjonalnego", decyduje ostatecznie określony typ doświadczenia.

\section{Podsumowanie}

Uwikłanie wielowiekowego problemu racjonalności $\mathrm{w}$ językowe uwarunkowania, na co wskazuje wiele współczesnych koncepcji tak w filozofii, jak i językoznawstwie, nie musi prowadzić do jego osłabienia czy odrzucenia. Jego relatywizacja na skutek używania terminologii metaforycznej do opisu tego, co określa się w działalności praktyczno-poznawczej człowieka jako „racjonalne”, pokazuje, że kategoria rozumu czy rozumności nie ma absolutystycznego charakteru. Perswazyjność i wartościujący charakter metaforycznych zwrotów konceptualizujących racjonalność - ujawniają one zakorzenienie w doświadczeniu schematów pojęciowych typu: góra-dół, dobre-złe, ruch ku czemuś, sekwencyjność, uporządkowanie czy manipulowanie rzeczami - wskazuje dodatkowo na intencjonalne nastawienia człowieka używającego zwrotów metaforycznych. Metafory rozumu i rozumności wpływają na tożsamość człowieka. Rozliczne metaforyczne określenia rozumu, racjonalnego działania i poznania budują u człowieka używającego ich poczucie integralności jego działania, współdziałania oraz tożsamości osobowej. Określanie siebie i innych mianem „racjonalnych” warunkuje, ułatwia, a także doskonali współdziałanie z innymi ludźmi. Uznawanie współtowarzyszy w działaniu czy poznawaniu za równie racjonalnych - działających według ucieleśnionych konceptualnych schematów w rodzaju „racjonalne jest jak dobieranie środków do celu" - jest praktyczno-poznawczym i zarazem moralnym zobowiązaniem, jakie podmiot przyjmuje najpierw wobec siebie, a potem wobec innych. Siłę tego zobowiązania oraz jego społecznych skutków (empatia, współpraca, porozumienie) wzmacniają metaforyczne zwroty, w których wskazuje się na elementarne i wspólne wszystkim działania 
o instrumentalnym charakterze; metafory o takim charakterze nie tylko opisują ale również motywują do działania. Koncepcja instrumentalnej racjonalności, racjonalności ograniczonej, o wiele lepiej tłumaczy działanie grupowe (instytucjonalne), jak również motywuje do niego poprzez odwoływanie się do ucieleśnionego doświadczenia, niż czyni to opozycyjna koncepcja kartezjańsko-kantowskiej racjonalności sub specie aeternitatis czy też „olimpijski model racjonalności”, których metaforyczne zwroty nie odwołują się do ucieleśnionego typu doświadczenia, a tylko do abstrakcyjnej idei.

Wniosek z powyższej uwagi jest jeden - metaforyczność w opisie racjonalności jest powszechną niedającą się wyrugować cechą dystynktywna, a wręcz konstytutywną, która tłumaczy każdy jej konkretny wymiar czy aspekt, wszelkie jej opozycje i dopełnienia w rodzaju nieracjonalności czy irracjonalności. W strukturze ucieleśnionej metaforyczności nierozumność, czy inaczej mówiąc irracjonalność, nie jest absolutnym przeciwieństwem racjonalności. Jest albo błędem poznawczym (bardziej nastawieniem czy ukierunkowaniem poznawczym), albo odstępstwem od racjonalności, w obu przypadkach zachodzącym w tym samym rodzaju pierwotnego doświadczenia. Tę właśnie zależność ujął trafnie D. Davidson, pisząc metaforycznie:

Idea irracjonalnego działania, przekonania, intencji, wnioskowania lub emocji jest paradoksalna. To, co irracjonalne nie jest jedynie nie-racjonalnym, które leży poza granicą racjonalnego; irracjonalność jest błędem w obrębie domu rozumu. [...] Irracjonalność procesem lub stanem mentalnym - racjonalnym procesem lub stanem - który zaszedł niepomyślnie (2004, s. 169).

Warto na koniec zauważyć, że metaforyczne ujęcie tak racjonalności, jak i nieracjonalności nie jest w wypowiedzi Davidsona (który, notabene, sens metafory sprowadzał do jej literalnego znaczenia) tylko stylistyczną figurą i klasycznym retorycznym ozdobnikiem, lecz ma ważny poznawczy walor - znosi opozycyjność i wzajemne wykluczanie się obu kategorii epistemologicznych i etycznych. Metafora odnosi zwycięstwo.

\section{Bibliografia}

Davidson D. (2004), Problems of Rationality, Clarendon Press, Oxford.

Hetmański M. (2009), Problem wiedzy niepewnej w koncepcji racjonalności ograniczonej, [w:] Z. Drozdowicz (red.), O racjonalności w nauce i w życiu społecznym, Wydawnictwo Naukowe Wydziału Nauk Społecznych UAM, Poznań, s. 157-174.

Hetmański M. (2018), Group Decision Making as Rational Undertaking: Rationality Attributed or Described?, [w:] M. Hetmański (red.), Rationality and Decision Making: From Normative Rules to Heuristics, Brill/Rodopi, Leiden-Boston, s. 23-53. 
Kleszcz R. (1998), O racjonalności. Studium epistemologiczno-metodologiczne, Wydawnictwo Uniwersytetu Łódzkiego, Łódź.

Lakoff G., Johnson M. (1999), Philosophy in the Flesh: The Embodied Mind and Its Challenge to Western Thought, Basic Books, New York.

Lakoff G., Johnson M (2010), Metafory w naszym życiu, Wydawnictwo Aletheia, Warszawa. Quinton A. (1975), Social Objects, „Proceedings of the Aristotelian Society” 75, s. 1-27.

Searle J. (2001), Rationality in Action, MIT Press, Cambridge.

Simon H. (1983), Reason in Human Affairs, Stanford University Press, Stanford.

Streszczenie: Racjonalność w ujęciu metaforycznym

Problem racjonalności, poza swoim ontologicznym, metodologicznym i epistemologicznym wymiarem, jest rozpatrywany również z lingwistycznej perspektywy. Racjonalność traktuje się wówczas jako złożone zjawisko, w którym pewne działania, poznanie i wiedza są wyobrażane i nazywane jako "racjonalne”. Chociaż perspektywę tę oskarża się niekiedy o relatywizm, w artykule argumentuje się na rzecz tezy, że takie podejście do problemu racjonalności jest obiecujące i owocne. Przedstawione są argumenty i koncepcje mówiące o metaforycznym sposobie opisu i przypisywania pewnym wybranym ludzkim czynom, współdziałaniom i poznawaniu cech racjonalności.

Słowa kluczowe: problem racjonalności, relatywizm, racjonalność działania i poznania, przypisywanie, metafory

Summary: Metaphoric Formulation of Rationality

Rationality problem is perceived, apart from its ontological, methodological, and epistemological aspects, also from the linguistic perspective. Rationality is considered then as a complex phenomenon in which certain human actions, cognition, and knowledge are named, defined, and conceptualized as "rational". However this perspective is sometimes accused of relativism, it is argued in the paper that such approach is promising and fruitful for the rationality problem. There are presented arguments and conceptions of the metaphorical describing and attributing selected human actions, cooperations and cognition as rational.

Keywords: rationality problem, relativism, rationality of action and cognition, attributing, metaphors 